\title{
A Study of Awareness of Cultural Heritage among the Teachers at University Level
}

\author{
Savita Srivastava \\ Department of Foundations of Education, Faculty of Education, Dayalbagh Educational Institute ( Deemed University), India
}

Copyright $@ 2015$ Horizon Research Publishing All rights reserved.

\begin{abstract}
Cultural Heritage means to inherent and cultivate the cultural disinclinations from one generation to next generation. It is possible by education as well as following the traditional livelihood of ours; it is conducted formal/consciously or informal/unconsciously. One of the traits of education is to hand on the cultural values and behaviour pattern of the society to its young and potential members. By this, means society achieves a basic social conformity and ensures that traditional modes of life are preserved. This has been called the conservative function of education. Handing on tradition is bound at times to be in conflict with a desire to initiate change. When a society is changing slowly, the new elements of its culture can be more easily absorbed. However, the rapid changes in the industrial society in the changing scenario have led to much conflict between old and new habits of life and thought. Here there are two contradictory functions of education which are both necessary and it can be shown that there are conditions of society under which these can be reconciled. [9]Hence in order to emphasize the need to link education and cultural heritage, its inheritance, preservation and cultivation, I decided to have a study of awareness of cultural heritage among the teachers at university level, so that we may have come to know that our teachers, formulating the 'Destiny of India' (as stated by Education Commission, 1964-66, 'Destiny of India is being shaped into their classroom')are aware about the Indian culture, its heritage or not because teacher are at the core of education structure, policy, values and cultural heritage to inculcate these values among our educands. Heritage awareness is a crucial part of any heritage conservation and management. The creation of awareness is time-consuming and it requires commitment and local support. It is often the most recognizable component of a heritage management. One of the most effective ways to build and maintain respect for community's heritage is through a selection of activities that raise public awareness and increase appreciation. The success of heritage conservation initiatives depends on the understanding and participation of the local community
\end{abstract}

Keywords Cultural Heritage, Elements of Indian Culture, National Symbols, Fine Arts, Performing Arts,
Social Structure

\section{Introductions}

To understand Cultural Heritage of India, it is necessary to know India in this context. Therefore, I have described in very brief to have a conceptual context of cultural heritage which makes India 'Mera Bharat Mahan'.

Land and People: Located in the South Peninsula of the Asia continent in India, a country triangular in shape tapering south wards to the Indian Ocean. It presents a great variety in topography, soils, vegetation, crops and climatic conditions as well as in its people, costumes, socio-economic conditions, languages and dialects. Yet it manifests a spectacle of cultural unity in diversity, historical continuity, stability of its democracy and its fast transformation into a resurgent economy through five year and rolling plans. Its constitution provides Secularism, Freedom, Republicanism, Federalism, Social Justice, Social Equality and Adult Franchise to the $13 \%$ of the World's population. [2.]

Stretching from Jammu and Kashmir in the North to Kanyakumari in the South from Rajasthan and Gujarat in the west to Arunachal Pradesh, Nagaland, Manipur and Mizoram in the East and with a land-frontier of 15,200 km and coastline of $6,100 \mathrm{kms}$, it ranks as the world's seventh largest country. No other land except the Soviet-Union and the Unites States surpasses it in the extent of are able acreage. It is the second largest next only to the people, republic of China. It is the first country, which undertook a major state policy of population control, to limit its exploding demographical growth, eroding its planned economic growth. [18.]

Elements of Indianness: Yet politically and culturally all Indians have something in common, some elements of Indianness, a particular way of looking at life and certain habits of thinking and feeling, peculiar to them the feeling, e.g. Indian son-in-law is a special person who gets favored treatment throughout India. Likewise, elders in the community, no matter which part of the country they come 
from, whatever language they speak, bless the young people in the same way and wish them the same good things in life. [4.]

Another quality of Indian culture, which is continuous and absorbent of new influences, is manifested in sacredness, whether it be in the 'peepal' tree, the river, the workman's tools, the plough or the temple, mosque, gurudwara or church. "They respect age and wisdom anything that gives energy is holy." They still have faith in the power of goodness, traits which are not essentially linked to religion. [3.]

Religious Groups: India is a land of multi religious society. Hindus and Muslims constitute $94 \%$ of the total population. The dominant Hinduism an ancient religion with roots in the early Aryan civilization and Vedic traditions has spread throughout the country absorbing and assembling many elements of the earlier indigenous religions. It is the religion of $83 \%$ of the population, professing the time honoured system and the dominant ethos of the society. Islam was brought into India by Muslim invaders in the 12th century. Adherents of Islam are descendants of their conquering invaders and of Hindus converted to Islam, under their influence. Hindus and Muslims are found in all cultural religions of the country. Their beliefs and practices vary as much according to region and social status as by their membership in one of the great religious groups. Religious adherents other than Hindus and Muslims constitute about $6 \%$ of the population. They include Sikhs (1.79\%), Buddhists (0.74\%), Jains (0.5\%) also called Parsis. [3.] The Buddhists and Christians are scattered in many religions and their way of life, vary with those of the regional subcultures, the Jains, Sikhs and Zoroastrians are more localized and have stronger communal identies. [5.]

Social Structure: Unity in diversity characterizes the Indian social structure and cultural pattern. Indian society is close society rather than ascribed society.

Language and Literature: The earliest language of Indian people was that of the Indus valley civilization which flourished from about 3500-2500 BC. The ordinary, spoken language of the Aryan people was Prakeit, which was allied to but different from the archaeology. Sanskrit of the early Vedic period, which was spoken by the Brahmans and the learned people. From A.D. 500-2000, many dialects (regional and local) had arisen such as Apbaramsa (the parent of the many modern Indian languages) Magdhi, ArdhMagdhi (both precise Prakrit speeches). Saureseni (the Mathura dialect), Avanti or Maharashtri, Paisachi, Vdichiya (Northwestern speech) Gandhari (northwestern Prakrit), Kekaya (West Indian speech) and some speeches in the south of India. [1.]

The Constitution of India (eighth schedule) recognizes 14 major Indian languages Assami, Bengali, Gujrati, Hindi, Kaunar, Kashmiri, Malyalam, Marathi, Oriya, Punjabi, Sanskrit, Tamil, Telguand Urdu. [9.]Sanskrit is a sister language of Latin and is linked with some of the European languages as well as with the culture and linguistic traditions of east Asia, central Asia and parts of South west Asia. English, which has become a powerful vehicle of expression and has been an important factor in modernizing liberalizing thought. It is the link language and plays a very useful role in the country. In modern times Indo-Aryan languages are spoken by the largest number of people in the country, approximately $74 \%$, the Dravidian by about $24 \%$ and the Austric by about $1.4 \%$ and the Sino-Tibetan by approximately $0.9 \%$ others language (and dialects such as Sindhi, Rajasthani, Kumauni, Garwali, Dogri, Mathili, Hindustani, Audi, BrajBhasha, Bhojpuri, Bundeli, Konkani, Holbi, Tulu, Kota, Toda, Keedangu, etc.) are being spoken by the remaining percentage of the speakers, as also by the tribal people and those inhabiting the remoter hill and jungle tracks. [4.]

Architecture and Arts: The earliest pre-historic rural settlement in this sub-continent are to be found in Baluchistan and Sindh now in Pakistan with the passage of time, large cities came to be established, two of which Harappa on the left bank of river Indus and Mohenjo-Daro on the right bank of Indus in Sind have been excavated. The earliest historical specimens of architecture are those of the Mauryan period. The rock-cut shrines in the Barabar hills of Bihar, a small monolithic rail at Saarnath, a throne in the disterior of the Bodh Gaya, some portions of Stupa Umbrellas at Sanchi and Saarnath as well as 'Yaksha' and 'Yakshi' statues are the production of this period. [5.]

Music\& Dance: In music data to pre-historic times, we have information about some of musical instruments such as harps, drums and whistler in the Indus valley civilization. Aryans had developed musical patterns for chanting their sacred hymns is however quite clear from the Rig-Veda and the Samveda. There are two broad systems of Indian music i.e. the Hindustani and the Karnataka. Indian music is built on 'Raga' and 'Tala' concepts. Moreover, Dance in India dates back to pre-historic times. It is claimed to have a divine origin. Brahma selected some features from each of the Vedas and evolved a fifth Veda - the Natya Kala. Rig-Veda (2000 BC - $1500 \mathrm{BC}$ ) the sacred book of the Hindus refers to Nritiya and dancer. The epics 'Ramayana' and 'Mahabharata' frequently mention dance on earth and heaven. However, we got complete details about the technique and forms of dance from (Natya Shastra). 2nd century BC -2 nd century AD there was two types of dances - Tandva (manly) and 'Lasya' (female), these are associated with Lord Siva and his wife GoddessParvati. [5.] In modern times there are some classical dances along with folk dances i.e. BhartaNatyam, Kachipudi, Kathak, Odisi, Manipuri, and Kathakali. Drama/Theatre: Indian theatre has an interesting history, which can be traced back to Vedic times. Charta's Natya Shastra was the first comprehensive work on dramaturgy. It lays down specifications for the design of the theatre construction of the stage etc. In modern theatre includes many innovations i.e. Nautanki, Nukkar, Swang, Khyal, Cinema, Raasleela, Documentary Film etc. [10.]

National Symbols: For the celebration of the 50th year of 
India's independence, Centre for Cultural Resource and Training, CCRT, under the aegis of Ministry of Culture, Government of India has introduced the National Symbols of India the Emblem, Flag, Anthem, Song, Calendars, Animal, Bird and Flower. These bring out the beauty and sensitivity represented in India's ancient philosophy and culture. National symbols provide an identity and the choice of symbols often reflect the values of a particular nation. The national Symbols of India are the manifestations of man's yearning for spiritual and emotional well-being, harmony with nature and are the expressions of his artistic creativity through the ages. [15.]

The flora and fauna have inspired the creative genius of the visual artists, poet, musician or dancer. The colonization of the stylized representation of the lotus can be seen in the architecture of the Bahai temple in Delhi and the rich heritage of the Mughal miniature pointing of the peacock of circa 1610 AD. National calendar traces the history of the ancient knowledge of calculating time, which has resulted in a variety of calendars in use today, and Asoka's philosophy and the great tradition of artistic expressions of his times have given India its National Emblem. [8.]

\section{Emergence of the problem}

Culture includes all internal and external activities of our life and in other words, it is the journey of a human being from pre-birth to after birth as a continuous process, which never ends. It is a way of living as well as philosophy of life. Our planet, cosmos, flora, fauna, our beliefs, traditions, values, religious aspects, rituals, customs, our attitudes, geographical surroundings, natural resources, history and civilization of a country are the elements of a culture. Now it is the responsibility of society to transmit, preserve and inculcate his own heritage in the form of culture. Society transmits this responsibility to education institutions and by educational institution, this major responsibility goes to the teachers as concrete implementer of the educational policy.

In India, Centre for Cultural Resource and Training, CCRT, under the aegis of Ministry of Culture, Govt. of India, is a pioneer institute to transmit, preserve and inherit Indian Culture. I also got a chance as a teacher- educator to attend an 'Orientation training programme' at regional centre of CCRT, Udaipur, in 2008 and simultaneously my half yearly reports regarding the accomplishment of the mission and vision of CCRT at my institute and in the region, are being send to CCRT for evaluation of my progress apropos to disseminate the cultural elements. After some years, CCRT provided an opportunity to me to attend 'Refresher Course' and 'Workshop' for renovation. Ultimately, they designated me 'District Recourse Person', by this responsibility, I organized a three-day workshop for government teachers from primary teachers to pre-degree level (senior secondary level) at my institute, and this workshop is sponsored by CCRT. Thus since 2008 onwards, associating with CCRT my ideas are being changed and an insight along with a vision is generated in me, a spirit is developed that being a citizen of India and teacher, it is my utmost moral and responsibility to inculcate, transmit, enhance, preserve and inherit the elements of Indian Culture among the society. Gradually this notion is being shaped in to a study the awareness among the teachers regarding Indian Cultural heritage.

The heritage of a community is essentially its resource for growth - a threshold for a forward movement even if that is rather evolutionary in character. It not only constitutes the spiritual resource of the community, as also of individuals it is an essential source of an identity deeply rooted in the past.

India has witnessed, in the millennia that are past, coming together of peoples from various places, of distinct racial stocks, of different religions, of diverse cultures and ideas, and this interactive togetherness has created a unique plurality - plurality of religions, of languages, of dress, of architecture - that yet draws upon and strengthens the same resource that has acquired eternality namely the 'Indianness', quintessentially. For the achievement of this Indianness in the fullest, the unique Indian plurality must continue to blossom unfettered and unhindered. Moreover, that will be possible only if these diversities the Totality of which constitutes the Indian existence - the very many 'heritages' of India - must have for them legitimate space and freedom not only to survive but also to grow and evolve as living cultures. That is why the Constitution of India guarantees cultural rights of the citizens in the following terms: "Any section of the citizens residing in the territory of India or any part thereof having a distinct language, script or culture of its own shall have the right to conserve the same". The Constitution further provides that it shall be the duty of every citizen of India to value and preserve the rich heritage of our composite culture.

All framed objectives of education are being completed in a concrete manner by the teachers. We cannot ignore the fundamental role of a teacher. 'When the librating art of a teacher meets the uncapped potential of a student, miracle unfolds.' Keeping this statement in the mind, society handovers to the teachers his own responsibility for shaping and framing the character as a noble human of his next generation. Ultimately in-service teachers play major role to up-date with knowledge and techniques of new dimensions, awareness along with our grass root level. We, the teachers will have to re-engineer the society and the nation. However, in India today, as indeed throughout the world, the pace of change poses unprecedented threats to the continuity of that cultural heritage. Aware of these threats, societies everywhere are expressing a growing demand for cultural preservation and renewal. In so doing they recognize the need to reinvigorate their own cultural identity and creativity. They recognize also that expenditures on culture are not a drain on the economy but a contribution to human and social development. Therefore, I raise this problem i.e. 'A Study of Awareness of Cultural Heritage among Teachers at university level'.

\section{Rationale of the study}

There has been lot of discussion on the issues like 
globalization, privatization, and rootlessness. Consequently, this scenario demands a serious discussion on the issue of national cultural heritage, to what extent at least the university teachers are aware of their national cultural heritage. In fact in present scenario there is an urgent require to maintain our cultural roots, traditions otherwise our forthcoming generations will never recognize the fundamental characteristic, facets and features of our country. How rich is its cultural values, beliefs fine arts, fundamental and applied arts etc. now we still trying to focus on that education pattern which was driven during the Vedic period i.e. ancient India.

The American Association of Colleges of Nursing (AACN) issued a position statement in 1997 regarding issues of diversity in nursing and nursing education. The AACN (1997) stated that, due to anticipation of an increasingly more diverse population in the next century, issues related to cultural diversity have become more central to nursing education. [14.] Nursing faculty has an obligation to prepare graduates who are aware of and sensitive to cultural issues (Capers, 1992; Chrisman, 1998).[7.]A variety of innovative approaches to teaching cultural diversity have been described in the literature and range from entire courses devoted to cultural issues (Lockhart \& Resick, 1997) [13.], to the introduction of a virtual classroom (Jackson, Yorker, \& Mitchein, 1996). [11.] Other approaches have used Internet assignments(Kirkpatrick, Brown, \& Atkins, 1998). [12.] Terms, such as cultural sensitivity, multicultural awareness, and cultural competence, or the lack of psychometrically sound instruments developed specifically for such evaluations. A valid assessment tool can help individuals identify their feelings about cultural diversity, which is prerequisite to deeper understanding of the phenomenon (Randall, 1994). [16.]

SWOT analysis is being conducted by Shankar B. \& Swamy C. (2013), 'Creating Awareness for Heritage Conservation in the City of Mysore: Issues and Policies', i.e. Strengths are awareness programmes viz. heritage walk, workshops and competition: debate, essay writing, painting, etc., initiated by Heritage Commissioners, special component of heritage conservation is being planned under JNNURM project, Networking of Institutions Philanthropist/Charitable Institution, heritage clubs, IHCN, UNESCO, NGOs, schools and colleges. Opportunities are setting up of Heritage Cell for planning, management, and control and resource mobilization., Scope for framing of Heritage Polices and IEC under JNNURM Tool Kit., Tourist Development Plan of State Government to boost heritage and culture. Moreover, in this SWOT analysis, weaknesses are insignificant effort for developing effective IEC materials for creating awareness, specific information to the public authorities or public for management of heritage assets including alterations and demolitions. There is no wide publicity drives. In addition, no mechanism for participation of people or owners of private buildings/ stakeholders. Threats are private owners and businesspersons resist/ oppose for maintaining the assets owned by them. Relocation of City Bus and Sub-urban terminals for pedestrianisation in the heritage core and restricting vehicles. [17.]

Indian constitution has a unique feature apropos to the cultural conservation, heritage, preservation and inculcation. They are mentioned in the Article 51A in the Constitution of India 1949.

51A. Fundamental duties It shall be the duty of every citizen of India (a) to abide by the Constitution and respect its ideals and institutions, the national Flag and the National Anthem; [18.]

(b) To cherish and follow the noble ideals which inspired our national struggle for freedom;

(c) To uphold and protect the sovereignty, unity and integrity of India;

(d) To defend the country and render national service when called upon to do so;

(e) to promote harmony and the spirit of common brotherhood amongst all the people of India transcending religious, linguistic and regional or sectional diversities; to renounce practices derogatory to the dignity of women;

(f) To value and preserve the rich heritage of our composite culture;

(g) To protect and improve the natural environment including forests, lakes, rivers and wild life, and to have compassion for living creatures;

(h) To develop the scientific temper, humanism and the spirit of inquiry and reform;

(i) To safeguard public property and to abjure violence;

(j) To strive towards excellence in all spheres of individual and collective activity so that the nation constantly rises to higher levels of Endeavour and achievement [18.]

Yet this social demand for culture greatly outstrips the resources available to government alone. In many countries, industrialized and developing alike, new funding mechanisms are being devised, based on the dual recognition that cultural activities can and should be as rationally managed and administered as other development programmes and that new alliances must be forged between the public and private sector, between the state and civil society. In addition, at a time when the marketplace reigns supreme, it is apparent that market process often fails to deliver a socially optimal level of goods and services in the culture sector and that cultural support delivered imaginatively in a market system is entirely consistent with pursuit of economic efficiency. [20.]

We are faced today with the challenge of not only industrialization, liberalization and urbanization but also to make sure that fresh air and clean water are available to our people. This is possible only by active participation by both the government and the people in resource conservation and management. This requires political will, education, and a change in the mindset of the people at large. Conservation of natural resources and culture can be achieved only through the empowerment of indigenous communities and their development. Finally, it is good to know that our efforts at 
preservation of natural resources have been recognized the world over with the latest survey by National Geographic magazine calling Indians as the most environment-friendly people. However, this puts an additional responsibility on Indians, that is, to not only protect, preserve and promote Indian cultural heritage and traditional knowledge, but also to lead the world in environment conservation through sustainable development through the ages.

Statement of the study

A Study of Awareness of Cultural Heritage among the Teachers at University Level.

Objectives of the study

The following objectives were framed to conduct this study:

1. To study the awareness of cultural heritage of male and female teachers at university level.

2. To study the awareness of male and female teachers at university level in context of national symbols (the first dimension of cultural heritage).

3. To study the awareness of male and female teachers at university level in context of cultural literature (the second dimension of cultural heritage).

4. To study the awareness of male and female teachers at university level in context of religion and history (the third dimension of cultural heritage).

5. To study the awareness of male and female teachers at university level in context of performing arts (the fourth dimension of cultural heritage).

6. To study the awareness of male and female teachers at university level in context of visual arts (the fifth dimension of cultural heritage).

Delimitations of the study

The study was conducted among the teachers at university level Dayalbagh Educational Institution (Deemed University), Agra, UP, India

Hypotheses of the study

1. The male and female teachers of Dayalbagh Educational Institute (Deemed University), Dayalbagh, Agra, UP, India are aware of the Cultural Heritage of India.

2. There exists no significant difference in the awareness of male and female teachers of Dayalbagh Educational Institute (Deemed University), Dayalbagh, Agra, UP, India, on the dimensions i.e. National Symbols, Cultural Literature, History and Religion, Performing Arts and Visual Arts of Cultural Heritage of India.

\section{Materials and Methods}

For this particular study, primarily descriptive survey method was selected because it is found to be the most appropriate technique for collecting information and opinions. Tools: A questionnaire regarding awareness of cultural heritage was prepared. Following three steps were followed to prepare the questionnaire:

Step I. Planning

Step II. Designing

Step III. Implementation

Step IV. Scoring and Final Drafting

Step I: Planning: Firstly the areas were planned to be taken into cultural heritage. Those areas are as following national symbols, Literature, History and Religion, Performing Art, Visual Art

These areas were planned with the help of the literature of Cultural Heritage of 'Centre for Cultural Resource and Training', CCRT, Regional Centre, Udaipur, Rajasthan, India under the aegis of Ministry of Culture, Government of India, New Delhi, India. Five key categories were identified to reflect the multidimensional nature of cultural awareness. These categories then were used as a blueprint to develop a scale to measure cultural awareness. The original scale contained 40 items using a 7-point Likert response format, ranging from, strongly disagree (1) to strongly agree (7). Table 1 summarizes the names of the categories and the number of items representing each category on the total scale. Phase One Participants and Procedure, Following approval by the Departmental Review Committee for the protectionof human subjects, a pilot version of the scale was administered to students who agreed to participate in a focus group. These participants helped the researchers clarify ambiguous items and develop a scale that accurately

Step II: Designing: After deciding the dimensions, items were framed under each dimension. Initially 60 items were written and after discussion with the expert members 40 items were finally retained which are presented dimension wise in Table 1 below.

Table 1. Dimensions and their Item Numbers

\begin{tabular}{|c|c|}
\hline Dimensions & Item Number \\
\hline I. National Symbols & $1,2,3,4,5,67,9,10,11,12,23,24,32,34,36,37=17$ \\
\hline $\begin{array}{c}\text { II.Cultural } \\
\text { Literature }\end{array}$ & $14,18,19,20,25,31=6$ \\
\hline $\begin{array}{c}\text { III.History } \\
\text { \&Religion }\end{array}$ & $8,13,16,19,21,20=6$ \\
\hline IV. Performing Art & $15,22,26,27,30=5$ \\
\hline V. Visual Art & $29,33,35,38,39,40=6$ \\
\hline
\end{tabular}

Step III: Implementation: The questionnaire thus prepared was implemented to find if any anomalies are there and then final draft was prepared.

Step IV: Scoring and Final Drafting: The questionnaire had content validity. After the final draft, one score was kept for correct answer to zero score for wrong answer.

Procedure: The questionnaire prepared for the study was administered to the teachers of Dayalbagh Educational Institute (Deemed University), Dayalbagh, Agra, UP, India. They were given twenty minutes to complete the questionnaire. After collecting the questionnaire, scoring was done. The raw data was subjected to analysis. 


\section{Results and Discussions}

Analysis of data and discussion of the results: The data has been analyzed under the following heads and the following abbreviations have been used:

$\begin{aligned} \text { i. } & \text { National Symbol } \\ \text { ii. } & \text { Literature } \\ \text { iii. } & \text { History and Religion } \\ \text { iv. } & \text { Performing Arts } \\ \text { v. } & \text { Visual Arts }\end{aligned}$

Percentage analysis of male and female teachers' scores in five dimensions of Cultural Heritage:

- $\quad$ t-ratio for the significance of difference between male and female teachers' on all the five dimensions of cultural heritage.

- $\quad$ Percentage analysis of male and female teachers' scores in five dimensions of cultural heritage.

The collected data has been analyzed in percentages. The class intervals of the scores have been made based on range found in every category vis-à-vis national symbols, cultural literature, history and religion, performing art and visual art. The percentage of male and female teachers in every category is presented in Table 2.below.

Table 2.of percentages reveals very interesting differences in male and female teachers. Female teachers are excelling in all the categories except two, in IVth category of performing arts percentages of male teachers are excelling than female teachers and in case of visual arts i.e. dimension Vth more percentages of male teachers are concentrated in $0-25 \%$ and $25-50 \%$ whereas major percentages of female teachers is concentrated in 50-75\% of marks. Secondly, Table 2.reveals that major percentages of female teachers score in highest-class intervals in case of cultural literature. Whereas male teachers scored more in 50-75\% marks category, it seems that there is definite difference in the performance of male teachers and female teachers on the second dimension vis-à-vis cultural literature. In case of third dimension table 2.reveals that there is not much difference in male and female teachers, i.e. both of them have comparable percentages in the dimension of history and religion. In case of fourth dimension, maximum male and female teachers are concentrated in $75-100 \%$ marks category whereas female teachers are also distributed in other score intervals.

Table 2. Percentages of Male and Female Teachers in the Five Dimensions of Cultural Heritage

\begin{tabular}{|c|c|c|c|c|c|}
\hline $\begin{array}{c}\text { Dimensions } \\
\text { of Cultural } \\
\text { Heritage }\end{array}$ & $\begin{array}{c}\text { Sex of } \\
\text { Teachers } \\
\rightarrow\end{array}$ & $\begin{array}{c}0-25 \\
\%\end{array}$ & $\begin{array}{c}25-50 \\
\%\end{array}$ & $50-75 \%$ & $\begin{array}{c}75-100 \\
\%\end{array}$ \\
\hline \multirow[t]{2}{*}{ I } & Male & $\mathrm{ff} \%$ & $\begin{array}{l}6 \\
1\end{array}$ & $\begin{array}{l}65 \\
11\end{array}$ & $\begin{array}{c}29 \\
5\end{array}$ \\
\hline & Female & & & $\begin{array}{c}82 \\
9\end{array}$ & $\begin{array}{c}18 \\
2\end{array}$ \\
\hline \multirow[t]{2}{*}{ II } & Male & & $\begin{array}{c}12 \\
2\end{array}$ & $\begin{array}{l}71 \\
12\end{array}$ & $\begin{array}{c}18 \\
3\end{array}$ \\
\hline & Female & & & $\begin{array}{c}18 \\
2 \\
\end{array}$ & $\begin{array}{c}82 \\
9 \\
\end{array}$ \\
\hline \multirow[t]{2}{*}{ III } & Male & & & $\begin{array}{c}41 \\
7\end{array}$ & $\begin{array}{l}59 \\
10\end{array}$ \\
\hline & Female & & & $\begin{array}{c}27 \\
3\end{array}$ & $\begin{array}{c}63 \\
8\end{array}$ \\
\hline \multirow[t]{2}{*}{ IV } & Male & $\begin{array}{l}6 \\
1 \\
\end{array}$ & & & $\begin{array}{l}94 \\
16 \\
\end{array}$ \\
\hline & Female & & $\begin{array}{l}9 \\
1 \\
\end{array}$ & $\begin{array}{l}9 \\
1 \\
\end{array}$ & $\begin{array}{c}82 \\
9 \\
\end{array}$ \\
\hline \multirow[t]{2}{*}{ V } & Male & $\begin{array}{c}29 \\
5\end{array}$ & $\begin{array}{c}36 \\
6\end{array}$ & $\begin{array}{c}29 \\
5\end{array}$ & $\begin{array}{l}6 \\
1\end{array}$ \\
\hline & Female & $\begin{array}{l}9 \\
1\end{array}$ & $\begin{array}{c}18 \\
2\end{array}$ & $\begin{array}{c}73 \\
8\end{array}$ & \\
\hline
\end{tabular}

$* \mathrm{f}=$ frequency

$* * \mathrm{f} \%=$ frequency percentage

In case of fifth category, maximum female teachers are concentrated in $50-75 \%$ category of marks whereas male teachers are concentrated in $0-25 \%$ and $25-50 \%$ category of marks. Thus, there seems to be a definite difference in the performance of male and female teachers in this dimension.

Hence, percentage analysis shows that male and female teachers of Dayalbagh Educational Institute (Deemed University) are aware of Cultural Heritage of India. The result supports the hypothesis (1) vis-à-vis the male and female teachers are aware of the Cultural Heritage of India t-ratio for the significance of difference between male and female teachers on all the five dimensions of cultural heritage.

Further, to see the significance of difference between female and male teachers, t-ratios have been calculated for each of the dimensions of cultural heritage, which are presented in Tale 3. below.

Table 3. t-Ratios for the Difference between Male and Female Teachers on All the Dimensions of Cultural Heritage

\begin{tabular}{|c|c|c|c|c|c|c|c|}
\hline & & $\mathrm{N}$ & $\mathrm{M}$ & $\mathrm{D}$ & $\sigma_{\mathrm{D}}$ & t-ratio & \\
\hline I & Male & 17 & 12.17 & 1.91 & 0.85 & 0.22 & Non significant \\
\hline & Female & 11 & 12.36 & 2.36 & & & \\
\hline II & Male & 17 & 3.47 & 1.07 & 0.32 & $4.78^{*}$ & Significant at 0.01 level \\
\hline & Female & 11 & 5. & 0.63 & & & Non significant \\
\hline III & Male & 17 & 4.59 & 1.00 & 0.36 & 1.64 & Non significant \\
\hline & Female & 11 & 5.18 & 0.87 & & & \\
\hline IV & Male & 17 & 4.29 & 0.99 & .38 & 0.29 & Non significant \\
\hline & Female & 11 & 4.18 & 0.98 & & & \\
\hline V & Male & 17 & 2.35 & 1.27 & .41 & 1.59 & \\
\hline
\end{tabular}

$* 0.05=1.71 ; * 0.01=2.06 ; \mathrm{df}=26$ 
It is very well revealed from Table 3. that t-ratio for the dimension I namely national symbols are not significant even at 0.05 level of confidence, which means male and female teachers do not differ on the dimension national symbol. Thus, the result does not provide sufficient evidence to accept the hypothesis (2), there are no significant difference in the awareness of male and female teachers on the dimension of national symbols of Culture Heritage.

Table 3. reveals that male and female teachers differ significantly on the dimension II of Cultural Heritage i.e. cultural literature at 0.01 level of confidence. Hence, the results provide sufficient evidence not to accept the hypothesis (2), In case of dimension of cultural literature.

Further, the observation of means from Table 3 for dimension II namely cultural literature of male and female teachers show mean of female teachers is higher than male teachers. This shows that female teachers are having significantly better awareness of cultural literature than male teachers are.

For dimension III, the t-ratio is found 1.64 but it is insignificant at 0.05 level of confidence thus it does not support the hypothesis (2), In case of dimension III namely history and religion. This means male and female teachers do not differ in their awareness in case of history and religion.

For dimension IV, t-ratio is not found to be significant at 0.01 level of confidence. Hence, the hypothesis (2) is not rejected in case of dimension IV namely performing arts. This means that male and female teachers do not differ in their awareness regarding performing arts.

Table 3. reveals that t-ratio for the dimension Vviz-a-viz visual art is found to be 1.59 but it is insignificant at 0.05 level of confidence hence the hypothesis (2), is not rejected in case of dimension visual art. It means male and female teachers do not differ in their awareness regarding visual arts.

Findings from this study should be interpreted with concern because of the relatively small number of participants from one geographic area. In addition, the sample is relatively small for factor analysis. Participants were from a single university, and therefore, findings are not generalizable to all teachers. Further development of the instrument with larger, diverse populations of teachers is rational. However, despite these limitations, positions as educators, their exposure to research.

Clinton (1996) defined culture as that which helps individuals adapt to their environments. Cultural awareness, sensitivity, and competence are concepts with definitions that are still evolving. Often, these terms are used interchangeably to refer to the same construct. In some cases, their definitions are implied, rather than explicitly stated. As more accreditation and other state agencies establish and attempts to enforce cultural competence guidelines (Lester, 1998), the terms cultural awareness, cultural sensitivity, and cultural competence increasingly are used or perceived as buzzwords. However, it is important not to allow these constructs to be dismissed as another set of new "politically correct" terms whose relevance will pass in time. (6.). Overall, participants in this study had high mean scores on the five dimensions of cultural awareness. These scores were obtained due to the core value of cultural awareness as CEC i.e. core course of co-curricular activity and rigorous assignments and continuous assessment by the university. It is possible that cultural awareness among teachers in this university did increase with program exposure.

In fact, in India, a government policies and non-government organizations' role-play a vital part for cultural conversation and heritage. It is a joint responsibility all of us. The National Commission on Urbanization and Model Building Bye-laws of Government of India has recommended that there is a need for incorporating the conservation principles into the basic curricula of architecture, engineering and town planning. Shankar B. and C. Swamy say, 'In order to create awareness of the value of heritage, suitably designed courses has to be included in the curricula of schools and colleges. Motivations and training of technical personnel in these lines will help in spreading the message of heritage conservation. Education and awareness programmes therefore are the most significant tool to achieve continued relationship with the past (16.).The $\mathrm{NCF}$ as constituted is expected to remedy this situation and to innovate effectively on the Indian culture scene. The importance of this effort is not only in what it brings in materially but in the vision, that it carries, that it will be the society that will, to a large extent, provide for, financially, for its cultural aspirations.

\section{Conclusion \& Recommendations}

\section{1. Conclusion}

The findings reveal that male and female teachers do have awareness regarding Cultural Heritage.

Female teachers overall score is better than male teachers. The more percentage of female teachers scores more on almost all the dimensions of Cultural Heritage. Female teachers are having significantly more awareness than male teachers in case of Cultural Literature are.

However, there is enough scope to include the heritage subject in the preparation of master plans under section 12(1) (f) of the KTCP Act and to contain separate heritage regulations, the present regulations are not adequate to meet the challenges of heritage areas. There is need to evolve detailed regulations for delineating heritage zones, and Development Control Regulations on lines of Hampi World Heritage Regulations for proper planning and conservation heritage areas in the City of Mysore. Further, efforts are required to create greater awareness among the people to include Information Education Communication, heritage walk, freedom walk, street plays, light and sound shows, Tonga tour, heritage festivals, heritage awards, heritage newspaper for promoting effective management and conservation of heritage area. 


\subsection{Recommendations}

In India, there is a proverb, 'Kos- Kospe badle pani,Kos Kos pe badlebani', it means every kilometer or change of place, the taste of water and language is also being changed. People's dialogue- delivery and presentation styles are being changed and this is India's cultural diversity and unity in diversity. And this cultural diversity is the grass root basis of Indian Culture and makes India unique. Consequently, for cultural heritage, there is strongly needed well-built policies and Programme of Action. In addition, only teacher interacts with the students on regularly basis. The teachers are implementing all policies, curriculum initiatives. In this way the pious will of teacher is utmost phenomena. Teacher plays a vital part. To make the teachers well versed with the Cultural Heritage of India and also in other countries there should be lectures on the Cultural Heritage as well as documentary films and classical movies can also be arranged, quizzes can be conducted, authentic written material can be provided for better understanding our cultural heritage. In-service and pre-services programme must be organized on short term basis and long term basis for the teachers at every stage or level of education (from pre-primary education to university education) as 'Orientation Training Programme', 'Refresher Course', and workshops as well as seminars\& conferences might be organized and all these programme must be mandatory for all in service and pre service teachers as a citizen of a particular country and here accountability of a teacher also plays a vital role .

Through this study we may be able to create awareness about the fundamental principles underlying the development of Indian culture so as to foster a spirit of National Integration. We may suggest to help University Grant Commission, UGC and Academic Staff Colleges, ASC, for implementation National Policy of Education in classroom teaching to the prospective Orientation Courses' participants and Refresher Courses' participants, which are 'In-Service Training Programmers', so that UGC-ASC may provide an opportunity to formulate methodologies in which Indian Culture and Creative Activities appearance as an integral part of the process of Learning and Teaching may be provided to the university teachers along with resource persons in this context. University Grant Commission Academic Staff Colleges and Ministry of Human Resource Development, MHRD may increase and enhance the accountability of the teachers at university level as well as all levels of Education beginning from the grass root level to higher education level, for cultural heritage and develop methodologies for the use of local resources in educational programmes and co-curricular activities in tune with teacher education as well as higher and lower secondary school curriculum and primary along with pre-primary curriculum. All Training Institutions from all levels of education i.e. Pre-Primary Level / Nursery Teacher Training Institutions, Secondary level of Teacher Training Institutions, PreServices Teacher Training Programmes of Education of all levels as well as In-Services Training Programmes of such levels of Education must be occupied with these facilities, inculcate these perspectives and should organize long term, short term training programmes as Centre for Cultural Resources and Training, CCRT, Ministry of Culture, Government of India use to organize and conduct Orientation training Programmes, Refresher Courses and workshops to transmit, inculcate and preserve the cultural elements and cultural heritage as pioneer agency in this field.

\section{Proposed Heritage Policies for Creating Awareness}

The existing programmes are not adequate and are to be conducted rigorously rather an on a piece meal approach, It needs to be given more professional touch to bring more systematic awareness involving various professionals, agencies and stakeholders in the field. Following new initiatives are proposed:

- $\quad$ Restructuring of Heritage Walks

- Freedom Walk: Freedom Walk be organized in heritage areas on all national level festivals like, Independence day, Republic day and birth days of important National leaders like Gandhi, Vivekananda, Subhas Chandra Bose, Freedom fighters etc., so that people will gather in large numbers to celebrate these events and also understand and respect, pay homage.

- $\quad$ Street Plays: Street plays with participants of the local community and eminent personalities from the area to be organized by involving institutions on a common platform to understand the issues related to tangible heritage in the city.

- Children' Books: Books depicting the history of the entire country and particularly the specific region.

- Heritage Products: Every zone has a proper list of its specific product and specifically i.e. inlay- work of Agra city in sculpture

- Elected Representative's Involvement

- Museum cum Information Centre

- Light and Sound Shows at historical monuments

- Heritage City Newspaper: Heritage and tourism department along with citizens group can jointly bring out newspaper exclusively discussing the issues related to heritage city and public awareness. This will spread the message of heritage awareness to more people in short period of time

- Training Administrators: Knowledge, skills and attitudes on heritage to be provided to the officials, who work in various departments related to heritage in all cities. Proper education and awareness programmes to these officials can go a long way in protecting and preserving the rich built heritage.

- Festivals: all religious festivals are very popular and world famous attracts tourists. In order to ensure community participation to raise the level of awareness and sense of belonging about the heritage, festivals, cultural festivals, World Heritage Day and heritage week may be organized every year. Cultural events, photo exhibition, drawing, paintings and essay competitions, lecture series and other related activities 
can be a part of the events to create more awareness on heritage to children and public.

- Heritage Awards: Heritage awards to be initiated to encourage people, individual, organizations, schools and media to take part in the competitions. This should be an annual feature and award to be decided by a panel consisting of many eminent personalities and this event can be organized on 18 April of every year to celebrate World Heritage Day.

- Promotion of Heritage in Education: Heritage educational programmes are successful only when the local community comes forward to support and initiate heritage related activities. This is possible when the local people to whom the very heritage belongs understands its values, takes pride and establish a sense of belonging. Social and cultural festivals play a greater role in generating awareness and mobilize communities. Community meetings, audio, visual shows, exhibitions, street plays, annual celebrations, cultural walks books and publications are all of effective means of cultural education

\section{Acknowledgements}

Indeed, I am very grateful and obliged to the Indian Government Organizations i. e. Centre for Cultural Resources and Training, CCRT, Ministry of Culture, Geological Survey of India and The Constitution of India for authentic insight and literature for Indian Cultural Heritage.

\section{REFERENCES}

[1] Agrawal, V.S. (1964). "The wheel Flag of India, "Varanasi.

[2] Arnold, Matthew (1946). "Culture and Anarchy", Cambridge university Press.

[3] Beal, Samuel, (1969). Trans, "Travels of Fashion and Sung-Yun, Buddhists Pilgrims from China to India, London.

[4] Benedict, Ruth (1935). "Patterns of Culture," Routledge Publications.
[5] Chopra, P.N. (6th Edition), (1984). "India: An Encyclopedic Survey,' S. Chand and Company Ltd., Ram Nagar, New Delhi.

[6] Clinton, J.F. (1996). Cultural diversity and health care in America: Knowledge fundamental to cultural competence in baccalaureate nursing students. Journal of Cultural Diversity

[7] Chrisman, N.J. (1998). Faculty infrastructure for cultural competence education. Journal of Nursing Education

[8] Director General, Centre for Cultural Resources and Training, Ministry of Culture, Govt. of India, New Delhi.

[9] Eliot, T.S. (1948). "Notes towards the Definition of Culture, Fabes.

[10] Havell, E.B. (1927), "A Handbook of Indian Art," London.

[11] Jackson, C., Yorker, B., \& Mitchem, P (1996). Teaching cultural diversity in a virtual classroom. Journal of Child and Adolescent Psychiatric Nursing

[12] Kirkpatrick, M.K., Brown, S., \& Atkins, T. (1998). Electronic education. Nurse Educator

[13] Lockhart, J.S., \& Resick, L.K. (1997). Teaching cultural competence: The value of experiential learning and community resources. Nurse Educator

[14] Lynn Rew, EdD, RNC, HNC, FAAN; Heather Becker, PhD; Jeff Cookston, $\mathrm{PhD}$; Sihlirin Khosropour, $\mathrm{PhD}$; and Stephanie Martinez, MSN, RN, Measuring Cultural Awareness in Nursing, Journal of Nursing Education, June 2003, Vol. 42, No. 6

[15] National Symbols, Reprint edition 2007, pub. By Williams Raymond,( 1978), 'Culture and Society and the Long Revolcits on 1961, Chalts and Windus.

[16] Randall, I. (1994). Assessing diversity. The Journal of Multicultural Nursing

[17] Shankar B. \& Swamy C., 'Creating Awareness for Heritage Conservation in the City of Mysore: Issues and Policies', International Journal of Modern Engineering Research (IJMER) www.ijmer.com Vol.3, Issue.2, March-April. 2013 pp-698-703 ISSN: 2249-6645

[18] The Constitution of India, Govt. of India

[19] http://www.portal.gsi.gov.in/gsilmages/information

[20] http://ncf.nic.in/ncf_role_why.htm 